\title{
Effects of Long-Term Administration of Freeze-Dried Chokeberry Juice to Rats
}

\author{
Teresa Adamska ${ }^{1}$, Małgorzata Ewertowska ${ }^{1}$, Ewa Ignatowicz ${ }^{2}$, Małgorzata Kujawska ${ }^{1}$, \\ Marcin Kidoń ${ }^{3}$, Arleta Matuszewska ${ }^{1}$, Jan Oszmiański ${ }^{4}$, Hanna Szaefer ${ }^{2}$ and \\ Jadwiga Jodynis-Liebert ${ }^{1, *}$
}

${ }^{1}$ Department of Toxicology, Poznań University of Medical Sciences, 30 Dojazd Str., 60-631 Poznań, Poland

${ }^{2}$ Department of Pharmaceutical Biochemistry, Poznań University of Medical Sciences, 4 Święcickiego Str., 60-761Poznań, Poland

${ }^{3}$ Institute of Food Technology of Plant Origin, Poznań University of Life Sciences, 31 Wojska Polskiego Str., 60-624 Poznań, Poland

${ }^{4}$ Department of Fruit, Vegetable and Cereal Technology, Environmental and Life Science University, $37 / 41$

Chełmońskiego Str., 51-630 Wrocław, Poland

\begin{abstract}
Polyphenolics can act as prooxidants leading to the generation of reactive oxygen species and electrophilic metabolites which bind to DNA, protein and glutathione. The aim of the present study was to evaluate potential adverse effects of the long-term dietary administration of freeze-dried chokeberry juice to rats.

Groups of 8 males and 8 females were exposed via diet to $0 ; 2 ; 6 ; 10 \mathrm{~g}$ juice/kg feed for 90 days. Mean food consumption and mean body weight gain of treated animals were comparable with controls. Changes in some hematological parameters were sporadic and non-dose-responsive. Several statistically significant changes in clinical chemistry parameters were considered no toxicologically relevant since they were of small magnitude and lacked correlating findings in histopathology. Histopathological examination did not reveal any changes that could be attributed to chokeberry juice intake. Determination of oxidative damage markers in the liver demonstrated no damage of lipids, proteins and DNA. Chokeberry juice intake improved antioxidant status of rats as evidenced by a decrease in the level of lipid peroxidation, an increase in reduced glutathione concentration and an increase in some antioxidant enzymes activity.

It could be concluded that freeze-dried chokeberry juice is safe at doses tested and can be used as a component of food supplements.
\end{abstract}

Keywords: Chokeberry, antioxidant activity, hematology, clinical chemistry.

\section{INTRODUCTION}

It is generally accepted that plant derived food exert beneficial effects on human health, particularly on some degenerative diseases. The mechanisms behind the protective actions of fruit and vegetables are not fully understood yet. One hypothesis is that fruit and vegetables contain factors that strengthen the defense against oxidative stress/reactive molecules. According to this hypothesis, the chronic intake of dietary antioxidants would lead to a sustained decrease in oxidative damage to key structures in the body including lipids, proteins and DNA [1].

Anthocyanidin- or proanthocyanidin-rich products are one of the most common food supplements on the market [2]. Berries of Aronia melanocarpa (chokeberry) are a rich source of these compounds. Many beneficial properties of chokeberry stem from its radical

*Address correspondence to this author at the Department of Toxicology, Poznań University of Medical Sciences, 30 Dojazd Str., 60-631 Poznań, Poland; Tel/Fax: 04861 8470721; E-mail: liebert@ump.edu.pl scavenging and antioxidant activity. Antimutagenic $[3,4]$ and anticancer $[5,6]$ properties have been demonstrated in cell lines and in in vivo experiments. Lipid-lowering, antiagregative and vasoactive action of chokeberry constituents contribute to its cardioprotective activity. In rats with hypercholesterolemia supplementation of diet with chokeberry juice caused a decrease in the levels of cholesterol, LDL and triglycerides [7]. In patients with metabolic syndrome beneficial effect of chokeberry juice on blood lipid concentration or antioxidant status and endothelial inflammation was observed. Antihypertensive properties of chokeberry extracts were confirmed in several clinical trials [8]. Moreover, hepatoprotective $[9,10]$ as well as gastroprotective [11] activity of chokeberry have been demonstrated in laboratory animals.

However, dietary phenolics have been shown to act as prooxidants in systems containing redox-active metals. In the presence of $\mathrm{O}_{2}$ transition metals such as copper and iron catalyze the redox cycling of phenolics leading to the formation of ROS and phenoxyl radicals 
that can damage DNA, lipids and other macromolecules [12]. Thus consumption of large amounts of flavonoids in the form of concentrated supplement may not be safe. Some authors have shown that oxidation of catechol B ring-containing flavonoids results in the formation of semiquinone and quinine-type metabolites. These compounds may act as electrophiles binding to cellular macromolecules [13]. For this reason consumption of large quantities of phenolic compounds in the form of diet supplements is not recommended [14]. Such prooxidant effects have been so far demonstrated in a series of in vitro studies but scarcely seen in animal models [15].

To the best of our knowledge, no studies have been reported in which the effects of long-term chokeberry intake on hematological, clinical chemistry parameters and tissues morphology were assessed. Hence, the aim of the current study was to investigate the safety of the dietary administration of freeze-dried chokeberry juice to rats for 90 days.

\section{MATERIALS AND METHODS}

\section{Test Material}

To commercially available chokeberry juice (Vincon, Konin, Poland) a proper amount of medium DE maltodextrin was added and the mixture was frozen at $50^{\circ} \mathrm{C}$ for $24 \mathrm{~h}$. Freeze-drying was performed in Labconco apparatus (USA). In the final product the ratio of maltodextrin and juice was 1:1. Maltodextrin was added to decrease hygroscopicity of dried juice. The content of polyphenols was determined by HPLC according to Oszmiański and Wojdyło [16] (Table 1). Trolox equivalents antioxidant capacity measured in the ABTS decolorisation assay [17] was 204.1 \pm 4.4 $\mathrm{mM} / \mathrm{g}$. Thirty one grams of freeze-dried material is equivalent to $100 \mathrm{ml}$ of fresh juice.

\section{Preparation of Dose Formulations}

Freeze-dried chokeberry juice was mixed into certified laboratory feed Labofeed H (ISO 22 000) to get concentration $2 ; 6 ; 10 \mathrm{~g} / \mathrm{kg}$ feed, and pellets were prepared. The homogeneity and the stability of test substance was checked three times during the study by the extraction of feed samples with methanol/water mixture $(1: 1)$ and spectrophotometric measurement of anthocyanin concentration [18].

\section{Chemicals}

The reagent kit for protein carbonyl determination was purchased from BioCell Corp.Ltd (New Zealand).
Agarose for comet assay was purchased from Prona (USA). Other chemicals were from Sigma-Aldrich (St Louis, USA) and local suppliers.

Table 1: Content of Polyphenolic Compounds in Chokeberry Juice (mg/100 g)

\begin{tabular}{|l|c|}
\hline \multicolumn{1}{|c|}{ Compounds } \\
\hline \hline Chlorogenic acid & 234.0 \\
Neochlorogenic acid & 234.3 \\
Cyanidin-3-galactoside & 178.6 \\
Cyanidin-3-arabinoside & 71.7 \\
Quercetin-3-galactoside & 19.0 \\
Quercetin-3-glucoside & 9.3 \\
Quercetin-3-vicianoside & 8.9 \\
Cyanidin-3-glucoside & 8.5 \\
Cyanidin-3-xyloside & 8.5 \\
Rutin & 8.1 \\
Quercetin-3-robinobioside & 4.5 \\
Polymeric procyanidins & 546.3 \\
\hline Sum & 1331.6 \\
\hline
\end{tabular}

\section{Animals}

Wistar rats bred in the Department of Toxicology, Poznań University of Medical Sciences, Poland were used. Animals were held (4 rats/cage) in polycarbonate cages (Techniplast, Italy) with wood shavings in a room maintained under $12 \mathrm{~h}$ light/dark cycle, $21 \pm 2^{\circ} \mathrm{C}, 37-55 \%$ relative humidity. Commercial diet (ISO 20000 certified laboratory feed Labofeed $\mathrm{H}$ ) and drinking water were available ad libitum.

\section{Experimental Design}

Forty male and forty female Wistar rats weighing $181 \pm 10 \mathrm{~g}$ and $135 \pm 10 \mathrm{~g}$, respectively, were divided randomly into four groups, 8 rats each: controls and exposed via diet to $2,6,10 \mathrm{~g}$ of chokeberry juice/kg feed for 90 consecutive days. Control animals were given feed with proper amounts of maltodextrin corresponding to that in the feed containing the highest dose of the test substance. Animals were observed twice a week for signs of toxicity. Body weights were recorded weekly during the study. Feed consumption was assessed by weighing the feeders. The intake of test substance was calculated weekly from the nominal test substance concentration, the feed consumption and mean body weight. At 91 day of feeding the rats were anesthetized with ketamine, blood was withdrawn from the heart and the organs were harvested for histopathological examinations. The weights of liver, kidneys, lung, heart, brain, spleen, testes were 
recorded. The livers were perfused with ice cold $1.15 \%$ $\mathrm{KCl}$ and portions were dissected and stored at $-80^{\circ} \mathrm{C}$ for determination of biochemical parameters.

The experiment was performed according to the guidelines of the Local Ethics Committee for animal experimentation.

\section{Clinical Pathology}

Hematological parameters evaluated included erythrocyte count (RBC), total and differential leukocyte count (WBC), hemoglobin (HGB), hematocrit (HCT), mean corpuscular volume (MCV), mean corpuscular hemoglobin $(\mathrm{MCH})$, mean corpuscular hemoglobin concentration (MCHC), platelet count (PLT). Hematological parameters were determined using an automated hematology analyser Cell-Dyn 3700 (Abbott Laboratories, Illinois, USA). Clinical chemistry parameters evaluated in separated serum included alanine aminotransferase, aspartate aminotransferase, alkaline phosphatase, total cholesterol, total protein, glucose, blood urea nitrogen, creatinine, calcium, sodium, potassium, inorganic phosphorus, chloride. Serum clinical chemistry parameters were determined using a chemistry analyser XL 300 (Erba Diagnostics, Mannheim, Germany) and reagents purchased from Biosystems (Spain).

\section{Anatomic Pathology}

At the time of necropsy the rats were examined grossly and the following organs were collected adrenals, aorta, bone marrow, brain, colon, esophagus, heart, ileum, kidneys, liver, lungs, ovaries, pancreas, pituitary gland, pancreas, spleen, stomach, testes, thyroid, trachea, urinary bladder, uterus. The tissues were fixed in $4 \%$ buffered formalin solution for $24 \mathrm{~h}$ and processed for paraffin embedding by standard methods. The paraffin blocks were sectioned at $5 \mu \mathrm{m}$ stained with hematoxylin \& eosin and examined by light microscopy.

\section{Biochemical Assays}

Lipid peroxidation in the liver homogenate was assessed by measuring thiobarbituric acid reactive substances (TBARS) [19]. Reduced glutathione content in the liver was assayed with Ellman's reagent [20]. Protein carbonyl concentration in the liver was determined by ELISA method according to the manufacturer instruction. Alkaline comet assay in the liver was performed according to the method described by Hartman et al. [21]. Antioxidant enzymes were assayed in the liver cytosol. Superoxide dismutase (SOD) activity was determined using spontaneous epinephrine oxidation [22]. Catalase (CAT) activity was determined by the measurement of hydrogen peroxide reduction [22]. Glutathione peroxidase (GPx) and glutathione reductase $(G R)$ activities were assayed by measuring NADPH oxidation using as a substrate hydrogen peroxide or oxidized glutathione, respectively [23].

\section{Statistical Analysis}

The GraphPad InStat statistical package (version 3) was used. The mean values and standard deviations were calculated separately for males and females. One way analysis of variance (ANOVA) followed by the Student-Newman-Keuls test for multiple comparisons was used. $p<0.05$ was considered the limit of significance.

\section{RESULTS AND DISCUSSION}

Analysis of the total content of anthocyanins in the diet preparations showed standard deviation of about $10 \%$ demonstrating that the test substance was stable and homogenously mixed into feed.

We have used dietary achievable dosing levels. On the basis of the feed consumption values and the nominal dietary concentration of chokeberry juice, the calculated mean daily intake of test substance was $0.15 ; 0.44 ; 0.71 \mathrm{~g} / \mathrm{kg} \mathrm{b.w./day} \mathrm{in} \mathrm{males} \mathrm{and} 0.15 ; 0.42$; $0.70 \mathrm{~g} / \mathrm{kg}$ b.w./day in females (Table 2).

Table 2: Mean Food Consumption and Final Body Weight of Rats Fed Chokeberry Juice

\begin{tabular}{|c|c|c|c|c|}
\hline \multirow{2}{*}{$\begin{array}{c}\text { Dosage level } \\
\text { (g/kg feed) }\end{array}$} & \multicolumn{2}{|c|}{$\begin{array}{c}\text { Food consumption } \\
\text { (g/rat/day) }\end{array}$} & \multicolumn{2}{c|}{$\begin{array}{c}\text { Final body weight } \\
\text { (g) }\end{array}$} \\
\cline { 2 - 5 } & Males & Females & 336.7 & Males \\
\hline \hline Control feed & 21.5 & 13.6 & 318.8 & 184.8 \\
\hline 2 & 23.4 & 15.2 & 323.8 & 195.4 \\
\hline 6 & 20.9 & 14.4 & 347.5 & 202.2 \\
\hline 10 & 21.0 & 13.4 & & \\
\hline
\end{tabular}


Table 3: Mean Calculated Test Substance Consumption

\begin{tabular}{|c|c|c|}
\hline $\begin{array}{c}\text { Dosage level } \\
\text { (g/kg feed) }\end{array}$ & \multicolumn{2}{|c|}{$\begin{array}{c}\text { Mean calculated test substance consumption } \\
\text { (g/kg b.w./day) }\end{array}$} \\
\cline { 2 - 3 } & Males & 0 \\
\hline \hline Control feed & 0 & 0.15 \\
\hline 2 & 0.15 & $0.11-0.22$ \\
\hline 6 & $0.11-0.22$ & 0.42 \\
\hline 10 & 0.44 & $0.32-0.51$ \\
\hline & $0.32-0.51$ & 0.70 \\
\hline
\end{tabular}

Means and ranges of test substance consumption are presented.

Mean body weight gain in the treated rats did not differ from that in controls throughout the experiment (data not shown). There were no statistically significant differences in final body weight and mean food consumption between controls and rats administered chokeberry juice (Table 3 ).

Statistically significant hematology findings are presented in Table 4. Changes in some white blood cells fractions, hematocrit, mean corpuscular volume, mean corpuscular hemoglobin, mean corpuscular hemoglobin concentration, were sporadic and nondose-responsive. Increased platelet count values in both sex mid- and high-dose groups by $21 \%-29 \%$, were likely treatment-related, however, they did not demonstrate a dose response relationship, had no histologic correlate and were determined to be within historical controls.

No toxicologically relevant changes were noticed in clinical chemistry parameters (Table 5). However, the following statistically significant changes were observed: increased alkaline phosphatase by $28 \%$ (low-dose male), decrease in alanine aminotransferase by $23 \%$ and $24 \%$ (low-dose male and female), decrease in chloride by $6 \%$ and $5 \%$ (low- and mid-dose male and female), increase in creatinine by $21 \%$ and $22 \%$ (mid-dose male and female), slight decrease in sodium by $2 \%$ (all treatment groups) and slight increase in calcium by $8 \%$ and $11 \%$ (mid-dose male

Table 4: Summary of Statistically Significant Hematology Findings in Rats Exposed to Chokeberry Juice

\begin{tabular}{|c|c|c|c|c|c|}
\hline \multirow{2}{*}{ Parameter } & \multicolumn{5}{|c|}{ Dietary chokeberry juice (g/kg feed) } \\
\hline & sex & 0 & 2 & 6 & 10 \\
\hline \multirow[t]{2}{*}{ Lymphocytes (\%) } & $\mathrm{M}$ & $87.9 \pm 2.8$ & $90.0 \pm 2.4$ & $88.1 \pm 1.9$ & $89.1 \pm 2.0$ \\
\hline & $\mathrm{F}$ & $93.0 \pm 1.1$ & $90.1 \pm 2.5^{\star}$ & $89.0 \pm 2.2^{*}$ & $90.8 \pm 2.3$ \\
\hline \multirow[t]{2}{*}{ Monocytes (\%) } & M & $3.5 \pm 0.9$ & $2.3 \pm 0.6^{*}$ & $3.0 \pm 0.7$ & $2.8 \pm 0.6$ \\
\hline & $\mathrm{F}$ & $2.0 \pm 0.6$ & $2.5 \pm 0.6$ & $2.9 \pm 1.0$ & $2.5 \pm 0.6$ \\
\hline \multirow[t]{2}{*}{ Basophiles (\%) } & M & $0.30 \pm 0.16$ & $0.16 \pm 0.11$ & $0.12 \pm 0.06^{*}$ & $0.23 \pm 0.14$ \\
\hline & $\mathrm{F}$ & $0.14 \pm 0.11$ & $0.18 \pm 0.10$ & $0.16 \pm 0.08$ & $0.26 \pm 0.11$ \\
\hline \multirow[t]{2}{*}{ Hematocrit (\%) } & M & $45 \pm 3$ & $47 \pm 2$ & $45 \pm 1$ & $46 \pm 1$ \\
\hline & $\mathrm{F}$ & $45 \pm 2$ & $46 \pm 2$ & $44 \pm 2$ & $49 \pm 2^{*}$ \\
\hline \multirow{2}{*}{$\begin{array}{l}\text { Mean corpuscular } \\
\text { volume }(\mathrm{fl})\end{array}$} & M & $53.1 \pm 3.4$ & $57.6 \pm 2.3^{*}$ & $54.0 \pm 1.4$ & $54.2 \pm 0.5$ \\
\hline & $\mathrm{F}$ & $56.9 \pm 3.4$ & $60.5 \pm 0.8^{*}$ & $57.5 \pm 1.2$ & $60.5 \pm 2.0^{*}$ \\
\hline \multirow{2}{*}{$\begin{array}{l}\text { Mean corpuscular } \\
\text { hemoglobin }(\mathrm{pg})\end{array}$} & $M$ & $17.1 \pm 1.1$ & $18.6 \pm 1.0^{*}$ & $18.1 \pm 0.6$ & $17.9 \pm 0.8$ \\
\hline & $\mathrm{F}$ & $18.3 \pm 0.4$ & $19.0 \pm 0.5$ & $19.1 \pm 0.8^{*}$ & $17.8 \pm 0.6$ \\
\hline \multirow{2}{*}{$\begin{array}{l}\text { Mean corpuscular hemoglobin } \\
\text { concentration }(\mathrm{g} / \mathrm{l})\end{array}$} & M & $321 \pm 16$ & $322 \pm 14$ & $335 \pm 9.5$ & $331 \pm 14$ \\
\hline & $\mathrm{F}$ & $321 \pm 14$ & $315 \pm 9.6$ & $332 \pm 9.6$ & $294 \pm 8.0^{*}$ \\
\hline \multirow[t]{2}{*}{ Platelet count (G/I) } & $M$ & $1108 \pm 128$ & $1192 \pm 118$ & $1414 \pm 183^{*}$ & $1429 \pm 150^{*}$ \\
\hline & $\mathrm{F}$ & $1110 \pm 83$ & $1239 \pm 73$ & $1338 \pm 113^{*}$ & $1354 \pm 177^{*}$ \\
\hline
\end{tabular}

Means and standard deviations are presented, $\mathrm{n}=8$.

*Significantly different from controls, $p<0.05$. 
Table 5: Summary of Statistically Significant Clinical Chemistry Findings in Rats Exposed to Chokeberry Juice

\begin{tabular}{|c|c|c|c|c|c|}
\hline \multirow{2}{*}{ Parameter } & \multicolumn{5}{|c|}{ Dietary chokeberry juice (g/kg feed) } \\
\hline & $\operatorname{sex}$ & 0 & 2 & 6 & 10 \\
\hline \multirow{2}{*}{$\begin{array}{l}\text { Alkaline phosphatase } \\
\qquad(\mathrm{U} / \mathrm{l})\end{array}$} & M & $107 \pm 15$ & $137 \pm 17^{*}$ & $125 \pm 17$ & $127 \pm 13$ \\
\hline & $\mathrm{F}$ & $118 \pm 14$ & $124 \pm 33$ & $122 \pm 11$ & $121 \pm 27$ \\
\hline \multirow{2}{*}{ Alanine aminotransferase (U/l) } & M & $61.1 \pm 10.7$ & $46.8 \pm 4.3^{*}$ & $54.7 \pm 5.7$ & $52.2 \pm 12.9$ \\
\hline & $\mathrm{F}$ & $61.6 \pm 11.0$ & $47.1 \pm 7.2^{*}$ & $49.2 \pm 9.2$ & $49.0 \pm 10.1$ \\
\hline \multirow{2}{*}{ Chloride (mmol/l) } & M & $94.8 \pm 1.4$ & $88.7 \pm 2.4^{*}$ & $90.0 \pm 5.8^{*}$ & $96.1 \pm 2.1$ \\
\hline & $\mathrm{F}$ & $95.7 \pm 3.0$ & $89.8 \pm 1.3^{*}$ & $90.9 \pm 6.0$ & $93.6 \pm 2.1$ \\
\hline \multirow{2}{*}{ Creatinine $(\mathrm{mmol} / \mathrm{l})$} & M & $51.1 \pm 4.9$ & $54.0 \pm 6.0$ & $61.9 \pm 5.8^{*}$ & $54.4 \pm 6.3$ \\
\hline & $\mathrm{F}$ & $50.1 \pm 5.1$ & $52.5 \pm 3.5$ & $61.1 \pm 5.6^{*}$ & $53.4 \pm 5.5$ \\
\hline \multirow{2}{*}{ Sodium (mmol/l) } & M & $144 \pm 1.9$ & $140 \pm 1.8^{*}$ & $141 \pm 0.9^{*}$ & $140 \pm 2.0^{*}$ \\
\hline & $\mathrm{F}$ & $144 \pm 1.0$ & $141 \pm 1.5^{\star}$ & $142 \pm 1.0^{*}$ & $142 \pm 1.2^{*}$ \\
\hline \multirow{2}{*}{ Calcium (mmol/l) } & M & $2.79 \pm 0.11$ & $2.72 \pm 0.07$ & $3.01 \pm 0.13^{*}$ & $2.80 \pm 0.17$ \\
\hline & $\mathrm{F}$ & $2.66 \pm 0.12$ & $2.69 \pm 0.18$ & $2.94 \pm 0.23^{*}$ & $2.82 \pm 0.11$ \\
\hline
\end{tabular}

Means and standard deviations are presented, $\mathrm{n}=8$.

*Significantly different from controls, $p<0.05$

and female). These changes were of small magnitude, were not observed in a dose-related manner and lacked correlating changes in other clinical chemistry parameters. Hence, they were considered as incidental biological variations, not treatment related adverse effects.

There were no significant differences in any relative mean organ weight between controls and treated rats (data not shown).

Microscopic examination of tissue sections did not reveal any pathology that could be attributed to chokeberry juice intake. All observed findings were consistent with normal background changes typical of this strain and age of rats and were randomly distributed among treated and control rats.

To examine potential adverse effect of long-term administration of chokeberry juice on hepatic cellular macromolecules, the markers of oxidative damage to lipids, protein and DNA were examined (Table 6). Lipid peroxidation level was slightly decreased in almost all treatment groups, however, the changes reached statistical significance only in mid-dose males and females (about 20\%). At the same level of dosing the increased concentration of reduced glutathione (by $20 \%$ ) was observed in males and females. The content of carbonyl groups in protein, a marker of protein oxidative damage, was not changed as compared to controls. Similarly, no changes in the level of DNA damage, determined by comet assay, were noticed.
Therefore, it could be concluded that the long-term intake of chokeberry juice in doses used does not cause oxidative damage to lipids, DNA and proteins.

Activity of three antioxidant hepatic enzymes was elevated in treated rats as compared to controls (Table 7). The most distinct, however, not dose-related increase was noted in catalase activity, by $77 \%$ $264 \%$. Superoxide dismutase activity was increased by about $30 \%$ only in two groups of females fed 2 and $6 \mathrm{~g}$ of juice $/ \mathrm{kg}$ feed. Glutathione peroxidase activity was elevated by $17 \%-69 \%$ in all treatment groups (except for the high-dose males), however, without any relation to dose. Response of glutathione reductase to chokeberry juice was the opposite since a moderate decrease in its activity $(16 \%-29 \%)$ was noted in treated rats. It could be hypothesized that some components of chokeberry juice might inhibit this enzyme.

Inhibition of GR activity by polyphenolic antioxidants has been demonstrated by other authors. Breinhold et al. [24] reported on the decrease in glutathione reductase activity in the liver of rats treated with quercetin and genistein. Decreased activity of GR was observed in rat liver cells incubated with delphinidin, (-) epicatechin, kaempherol, quercetin, luteolin, naringenin and apigenin [25]. Other authors [26] postulated that the decreased activity of GR facilitates oxidation of glutathione leading to the more effective removal of hydrogen peroxide. As a result the antioxidant defense system of the tissue is enhanced. 
Table 6: Effect of Chokeberry Juice on Oxidative Stress Parameters in the Liver of Rats

\begin{tabular}{|c|c|c|c|c|c|}
\hline \multirow{2}{*}{ Parameter } & \multicolumn{5}{|c|}{ Dietary chokeberry juice (g/kg feed) } \\
\hline & $\operatorname{sex}$ & 0 & 2 & 6 & 10 \\
\hline \multirow[t]{2}{*}{$\begin{array}{c}\text { Lipid peroxidation } \\
\text { (nmol TBARS/mg protein) }\end{array}$} & M & $15.8 \pm 3.0$ & $14.8 \pm 2.7$ & $\begin{array}{c}12.1 \pm 0.9^{*} \\
{[\downarrow 24 \%]}\end{array}$ & $17.2 \pm 2.0$ \\
\hline & $\mathrm{F}$ & $15.5 \pm 2.8$ & $13.1 \pm 1.4$ & $12.4 \pm 1.6$ & $13.4 \pm 1.5$ \\
\hline \multirow{2}{*}{$\begin{array}{l}\text { Carbonyl groups } \\
\text { (nmol/mg protein) }\end{array}$} & $\mathrm{M}$ & $0.24 \pm 0.03$ & $0.23 \pm 0.02$ & $0.24 \pm 0.06$ & $0.22 \pm 0.04$ \\
\hline & $\mathrm{F}$ & $0.17 \pm 0.01$ & $0.14 \pm 0.02$ & $0.16 \pm 0.02$ & $0.16 \pm 0.02$ \\
\hline \multirow{2}{*}{$\begin{array}{l}\text { DNA damage } \\
\text { (arbitrary points) }\end{array}$} & $\mathrm{M}$ & $64 \pm 5$ & $62 \pm 7$ & $64 \pm 5$ & $65 \pm 7$ \\
\hline & $\mathrm{F}$ & $65 \pm 4$ & $68 \pm 6$ & $63 \pm 7$ & $67 \pm 6$ \\
\hline \multirow{2}{*}{$\begin{array}{l}\text { Reduced glutathione } \\
\text { (nmol/g liver) }\end{array}$} & $\mathrm{M}$ & $2.49 \pm 0.29$ & $2.35 \pm 0.23$ & $\begin{array}{c}3.03 \pm 0.37^{*} \\
{[\uparrow 20 \%]}\end{array}$ & $2.58 \pm 0.25$ \\
\hline & $\mathrm{F}$ & $2.06 \pm 0.25$ & $1.92 \pm 0.31$ & $\begin{array}{c}2.52 \pm 0.28^{*} \\
{[\uparrow 23 \%]}\end{array}$ & $1.87 \pm 0.16$ \\
\hline
\end{tabular}

Means and standard deviations are presented, $\mathrm{n}=8$.

*Significantly different from controls, $p<0.05$.

TBARS - thiobarbituric acid reactive substances.

Values in parentheses express percentage of change.

Table 7: Effect of Chokeberry Juice on Antioxidant Enzymes Activity in the Liver of Rats

\begin{tabular}{|c|c|c|c|c|c|}
\hline \multirow{2}{*}{ Parameter } & \multicolumn{5}{|c|}{ Dietary chokeberry juice (g/kg feed) } \\
\hline & sex & 0 & 2 & 6 & 10 \\
\hline \multirow[t]{2}{*}{$\begin{array}{l}\text { Catalase (CAT } \\
\text { (U/mg protein) }\end{array}$} & $\mathrm{M}$ & $3.20 \pm 0.51$ & $\begin{array}{c}8.71 \pm 0.95^{*} \\
{[\uparrow 172 \%]}\end{array}$ & $\begin{array}{c}11.66 \pm 1.16^{*} \\
{[\uparrow 264 \%]}\end{array}$ & $\begin{array}{c}5.66 \pm 0.66^{*} \\
{[\uparrow 77 \%]}\end{array}$ \\
\hline & $\mathrm{F}$ & $1.81 \pm 0.19$ & $\begin{array}{c}3.73 \pm 0.57^{*} \\
{[\uparrow 106 \%]}\end{array}$ & $2.46 \pm 0.20$ & $\begin{array}{c}6.42 \pm 0.93^{*} \\
{[\uparrow 254 \%]}\end{array}$ \\
\hline \multirow{2}{*}{$\begin{array}{c}\text { Superoxide } \\
\text { dismutase (SOD) } \\
\text { (U/mg protein) }\end{array}$} & $\mathrm{M}$ & $27.4 \pm 3,1$ & $27.7 \pm 3.2$ & $26.9 \pm 3,3$ & $25.4 \pm 3.4$ \\
\hline & $\mathrm{F}$ & $25.7 \pm 3,4$ & $\begin{array}{c}33.0 \pm 2.3^{*} \\
{[\uparrow 29 \%]}\end{array}$ & $\begin{array}{c}32.5 \pm 3.5^{\star} \\
{[\uparrow 27 \%]}\end{array}$ & $27.4 \pm 4.2$ \\
\hline \multirow[t]{2}{*}{$\begin{array}{l}\text { Glutathione peroxidase (GPx) (nmol } \\
\text { NADPH /min/mg protein) }\end{array}$} & $\mathrm{M}$ & $353 \pm 35$ & $\begin{array}{c}598 \pm 53^{*} \\
{[\uparrow 69 \%]}\end{array}$ & $\begin{array}{c}425 \pm 57^{*} \\
{[\uparrow 20 \%]}\end{array}$ & $413 \pm 47$ \\
\hline & $\mathrm{F}$ & $481 \pm 44$ & $\begin{array}{c}562 \pm 46^{*} \\
{[\uparrow 17 \%]}\end{array}$ & $\begin{array}{c}596 \pm 41^{*} \\
{[\uparrow 24 \%]}\end{array}$ & $\begin{array}{c}570 \pm 65^{*} \\
{[\uparrow 18 \%]}\end{array}$ \\
\hline \multirow[t]{2}{*}{$\begin{array}{l}\text { Glutathione reductase (GR) (nmol } \\
\text { NADPH /min/mg protein) }\end{array}$} & $\mathrm{M}$ & $111.9 \pm 14.2$ & $\begin{array}{c}91.5 \pm 11.5^{*} \\
{[\downarrow 18 \%]}\end{array}$ & $\begin{array}{c}93.2 \pm 12.2^{*} \\
{[\downarrow 17 \%]}\end{array}$ & $96.9 \pm 11.4$ \\
\hline & $\mathrm{F}$ & $102.7 \pm 13.9$ & $\begin{array}{c}86.6 \pm 8.0^{*} \\
{[\downarrow 16 \%]}\end{array}$ & $\begin{array}{c}82.7 \pm 10.2^{*} \\
{[\downarrow 20 \%]}\end{array}$ & $\begin{array}{c}73.2 \pm 12.3^{*} \\
{[\downarrow 29 \%]}\end{array}$ \\
\hline \multirow{2}{*}{$\begin{array}{c}\text { Glutathione } \\
\text { S-transferase (GST) (nmol } \\
\text { CDNB/min/mg protein) }\end{array}$} & $\mathrm{M}$ & $813 \pm 90$ & $783 \pm 65$ & $761 \pm 89$ & $734 \pm 66$ \\
\hline & $\mathrm{F}$ & $535 \pm 81$ & $610 \pm 72$ & $629 \pm 83$ & $564 \pm 50$ \\
\hline
\end{tabular}

Means and standard deviations are presented, $n=8$.

*Significantly different from controls.

Values in parentheses express percentage of change.

In our previous study, fresh chokeberry juice was administered to male rats for 28 days at a dose 10 $\mathrm{ml} / \mathrm{kg} \mathrm{b.w}$. and no changes in the activity of CAT, GPx and GR were observed but in contrast to the current results, the SOD activity was decreased [10]. Thus, it could be suggested that the response of antioxidant enzymes to chokeberry juice intake depends on the time of feeding and the modulation of their activity occurs as a result of long-term administration.

Overall, the effect of chokeberry juice on antioxidant status of rats can be considered beneficial. According 
to Nelson et al. [27] induction of antioxidant enzymes by diet phytochemicals is more advantageous than supplementation with exogenous antioxidants whose efficiency is limited since they are stoichiometrically rapidly consumed in processes of antioxidant defense.

\section{CONCLUSION}

The results of the current study demonstrated that rats well tolerated freeze-dried chokeberry juice up to $0.7 \mathrm{~g} / \mathrm{kg}$ b.w./day for 90 days. The juice tested did not induce any significant changes in hematological and clinical chemistry parameters as well as in organs and tissues morphology. Moreover, long-term supplementation with chokeberry juice enhanced antioxidant status in the liver of rats. However, the presented data about the lack of adverse effects of chokeberry juice derive from the experiment on small population of animals and cannot be referred directly to humans. Hence, further observational studies would be recommended to prove the safety of the material tested as a potential component of food supplements.

\section{ACKNOWLEDGEMENTS}

This work was supported by Operational Programme Innovative Economy POIG 01.01.02-00-061/09.

\section{CONFLICT OF INTERESTS STATEMENT}

The authors declare that there is no conflict of interests.

\section{REFERENCES}

[1] Dragsted LO, Pedersen A, Hermetter A, et al. The 6-a-day study: effects of fruit and vegetables on markers of oxidative stress and antioxidative defense in healthy nonsmokers. Am J Clin Nutr 2004; 79: 1060-72.

[2] Espín JC, García-Conesa MT, Tomás-Barberán FA. Nutraceuticals: facts and fiction. Phytochemistry 2007; 68: 2986-3008. http://dx.doi.org/10.1016/j.phytochem.2007.09.014

[3] Pool-Zobel BL, Bub A, Schröder N, Rechkemmer G. Anthocyanins are potent antioxidants in model systems but do not reduce endogenous oxidative DNA damage in human colon cells. Eur J Nutr 1999; 38: 227-34. http://dx.doi.org/10.1007/s003940050065

[4] Gasiorowski K, Szyba K, Brokos B, Kołaczyńska B, Jankowiak-Włodarczyk M, Oszmiański J. Antimutagenic activity of anthocyanins isolated from Aronia melanocarpa fruits. Cancer Lett 1997; 119: 37-46. http://dx.doi.org/10.1016/S0304-3835(97)00248-6

[5] Jing P, Bomser JA, Schwartz SJ, He J, Magnuson BA, Giusti MM. Structure-function relationships of anthocyanins from various anthocyanin-rich extracts on the inhibition of colon cancer cell growth. J Agric Food Chem 2008; 56: 9391-98. http://dx.doi.org/10.1021/jf8005917

[6] Lala G, Malia M, Zhao C, et al. Anthocyanin-rich extracts inhibit multiple biomarkers of colon cancer in rats. Nutr Cancer 2006; 54: 84-93.

http://dx.doi.org/10.1207/s15327914nc5401 10
[7] Valcheva-Kuzmanova S, Kuzmanov K, Mihova V, Krasnaliev I, Borisova P, Belcheva A. Antihyperlipidemic effect of Aronia melanocarpa fruit juice in rats fed a high-cholesterol diet. Plant Foods Hum Nutr 2007; 62: 19-24.

http://dx.doi.org/10.1007/s11130-006-0036-2

[8] Kokotkiewicz A, Jaremicz Z, Luczkiewicz M. Aronia plants: a review of traditional use, biological activities, and perspectives for modern medicine. J Med Food 2010; 13: 255-69.

http://dx.doi.org/10.1089/jmf.2009.0062

[9] Valcheva-Kuzmanova S, Borisova P, Galunska B, Krasnaliev I, Belcheva A. Hepatoprotective effect of the natural fruit juice from Aronia melanocarpa on carbon tetrachloride-induced acute liver damage in rats. Exp Toxicol Pathol 2004; 56: 195201.

http://dx.doi.org/10.1016/j.etp.2004.04.012

[10] Kujawska M, Ignatowicz E, Ewertowska M, Oszmiański J, Jodynis-Liebert J. Protective effect of chokeberry on chemical-induced oxidative stress in rat. Hum Exp Toxicol 2011; 30: 199-208.

http://dx.doi.org/10.1177/0960327110371697

[11] Matsumoto M, Hara H, Chiji $\mathrm{H}$ and Kasai T. Gastroprotective effect of red pigments in black chokeberry fruit (Aronia melanocarpa Elliot) on acute gastric hemorrhagic lesions in rats. J Agric Food Chem 2004; 52: 2226-29. http://dx.doi.org/10.1021/jf034818q

[12] Galati G, O'Brien PJ. Potential toxicity of flavonoids and other dietary phenolics: significance for their chemopreventive and anticancer properties. Free Radic Biol Med 2004; 3: 287-303. http://dx.doi.org/10.1016/j.freeradbiomed.2004.04.034

[13] Awad HM, Boersma MG, Boeren S, van Bladeren PJ, Vervoort J, Rietjens IM. Structure-activity study on the quinone/quinone methide chemistry of flavonoids. Chem Res Toxicol 2001; 14: 398-408.

http://dx.doi.org/10.1021/tx000216e

[14] Halliwell B. Dietary polyphenols: good, bad, or indifferent for your health? Cardiovasc Res 2007; 73: 341-47.

\section{http://dx.doi.org/10.1016/j.cardiores.2006.10.004}

[15] Scalbert A, Manach C, Morand C, Rémésy C, Jiménez L. Dietary polyphenols and the prevention of diseases. Crit Rev Food Sci Nutr 2005; 45: 287-306. http://dx.doi.org/10.1080/1040869059096

[16] Oszmiański J, Wojdyło A. Aronia melanocarpa phenolics and their antioxidant activity. Eur Food Res Technol 2005; 221 809-13. http://dx.doi.org/10.1007/s00217-005-0002-5

[17] Re R, Pellegrini N, Proteggente A, Pannala A, Yang M, RiceEvans C. Antioxidant activity applying an improved ABTS radical cation decolorization assay. Free Radic Biol Med 1999; 26: 1231-37. http://dx.doi.org/10.1016/S0891-5849(98)00315-3

[18] Giusti MM, Wrolstad RE. Characterization and measurement of anthocyanins by UV-visible spectroscopy. In: Handbook of Food Analytical Chemistry. John Wiley and Sons, New York 2005; pp. 19-31. http://dx.doi.org/10.1002/0471142913.faf0102s00

[19] Sanz MJ, Ferrandiz ML, Cejudo M, et al. Influence of a series of natural flavonoids on free radical generating systems and oxidative stress. Xenobiotica 1994; 24 : 689-99. http://dx.doi.org/10.3109/00498259409043270

[20] Sedlak J, Lindsay RH. Estimation of total, protein-bound, and nonprotein sulfhydryl groups in tissue with Ellman's reagent. Anal Biochem 1968; 25: 192-205. http://dx.doi.org/10.1016/0003-2697(68)90092-4

[21] Hartmann A, Agurel E, Beevers EIC, et al. Recommendations for conducting the in vivo alkaline Comet assay. Mutagenesis 2003; 18: 45-51. http://dx.doi.org/10.1093/mutage/18.1.45

[22] Jodynis-Liebert J, Murias M, Błoszyk E. Effect of sesquiterpene lactones on antioxidant enzymes and some 
drug-metabolizing enzymes in rat liver and kidney. Planta Med 2000; 66: 199-205

http://dx.doi.org/10.1055/s-2000-8566

[23] Mohandas J, Marshall JJ, Duggin GG, Horvath JS, Tiller DJ. Low activities of glutathione-related enzymes as factors in the genesis of urinary bladder cancer. Cancer Res 1984; 44: 5086-91.

[24] Breinholt V, Lauridsen ST, Dragsted LO. Differential effects of dietary flavonoids on drug metabolizing and antioxidant enzymes in female rat. Xenobiotica 1999; 12: 1227-40. http://dx.doi.org/10.1080/004982599237903

[25] Galvez J, de la Cruz JP, Zarzuelo A, Sanchez de la Cuesta F. Flavonoid inhibition of enzymic and nonenzymic lipid peroxidation in rat liver differs from its influence on the glutathione-related enzymes. Pharmacology 1995; 51: 12733.

http://dx.doi.org/10.1159/000139325

[26] Gonzalez-Correa JA, de la Cruz JP, Gordillo J, Urena I, Redondo R, Sanchez de la Cuesta F. Effects of silymarin MZ-80 on hepatic oxidation stress in rats with biliary obstruction. Pharmacology 2002; 64: 18-2.

http://dx.doi.org/10.1159/000056146

[27] Nelson SK, Bose SK, Grunwald GK, Myhill P, McCord JM. The induction of human superoxide dismutase and catalase in vivo: a fundamentally new approach to antioxidant therapy. Free Radic Biol Med 2006; 40: 341-7. http://dx.doi.org/10.1016/i.freeradbiomed.2005.08.043

Received on 19-03-2014

DOI: http://dx.doi.org/10.6000/1927-5951.2014.04.02.11

(C) 2014 Adamska et al.; Licensee Lifescience Global.

This is an open access article licensed under the terms of the Creative Commons Attribution Non-Commercial License (http://creativecommons.org/licenses/by-nc/3.0/) which permits unrestricted, non-commercial use, distribution and reproduction in any medium, provided the work is properly cited. 